\title{
Influences of Salinity on Embryonic and Larval Development of Striped Catfish Pangasianodon hypophthalmus
}

\author{
Farzana Hossain ${ }^{1}$, S. M. Majharul Islam¹, Mohammad Ashaf-Ud-Doulah', Md Shaha Ali², \\ Md Sadiqul Islam³, Christopher Brown ${ }^{4}$ and Md Shahjahan ${ }^{1 *}$ \\ 1 Laboratory of Fish Ecophysiology, Department of Fisheries Management, Bangladesh Agricultural University, Mymensingh, \\ Bangladesh, ${ }^{2}$ Freshwater Research Station, Bangladesh Fisheries Research Institute, Mymensingh, Bangladesh, \\ ${ }^{3}$ Department of Marine Fisheries Science, Bangladesh Agricultural University, Mymensingh, Bangladesh, ${ }^{4}$ World Fisheries \\ University Pilot Programme, Pukyong National University, Busan, South Korea
}

\section{OPEN ACCESS}

Edited by:

Mikko Juhani Nikinmaa,

University of Turku, Finland

Reviewed by:

Jitendra Kumar Sundaray,

Indian Council of Agricultural

Research, India

Hon Jung Liew,

Universiti Malaysia Terengganu,

Malaysia

${ }^{*}$ Correspondence: Md Shahjahan

mdshahjahan@bau.edu.bd

Specialty section:

This article was submitted to

Aquatic Physiology,

a section of the journal

Frontiers in Marine Science

Received: 23 September 2021 Accepted: 01 November 2021 Published: 30 November 2021

Citation:

Hossain F, Islam SMM,

Ashaf-Ud-Doulah M, Ali MS, Islam MS, Brown C and Shahjahan M

(2021) Influences of Salinity on

Embryonic and Larval Development of Striped Catfish Pangasianodon

hypophthalmus.

Front. Mar. Sci. 8:781951. doi: 10.3389/fmars.2021.781951
Salinity intrusion in coastal areas due to climate change is alarming. In this study, the effects of salinity on embryonic and larval development of striped catfish (Pangasianodon hypophthalmus) were studied experimentally. Embryos and larvae were exposed to seven salinity treatments $(0,2,4,6,8,10$, and 12 ppt), each with three replications. Considerable survivability of embryos was recorded up to 6 ppt salinity. Mortality of embryos significantly increased at 8 and 10 ppt salinity, and 100\% mortality was displayed within $12 \mathrm{~h}$ of exposure at $12 \mathrm{ppt}$ salinity. The rate of hatching was significantly reduced at 8 and $10 \mathrm{ppt}$ salinity. The $24 \mathrm{~h}$ lethal concentration (LC50) value of salinity for embryo was 11.24 ppt. Different types of deformities, such as undeveloped yolk sac, elongated gastrula yolk sac, and yolk sac bud, were highest at 10 ppt salinity. Similar to the embryo, considerable survivability of larvae was recorded up to $6 \mathrm{ppt}$ salinity, and $100 \%$ mortalities were found within $24 \mathrm{~h}$ of exposure at $12 \mathrm{ppt}$ salinity. The 24 and 48 h LC50 values of salinity for larvae were 10.63 and 8.48 ppt, respectively. Several types of deformities, including yolk sac ulceration, spine scoliosis, tail bent, yolk sac edema, and compromised swim bladder inflation, were highest at 10 ppt salinity after $48 \mathrm{~h}$ of exposure. Within $24 \mathrm{~h}$ of exposure, about $80 \%$ yolk sac of the larvae was absorbed at 8 and 10 ppt salinity, while 30\%-50\% yolk sac was absorbed at 0-6 ppt salinity. Growth rates in terms of length and weight were higher at 0, 2, and 4 ppt salinity and moderate at 6 and 8 ppt salinity. Overall, the current findings define the limits to optimize hatchery procedures for the culture of this species in low saline brackish water.

Keywords: aquaculture, brackish water, early development, oxygen consumption, pangas

\section{INTRODUCTION}

Climate changes induced salinity intrusions in the coastal areas are cause for serious concern in tropical and subtropical countries (Rabbani et al., 2013). For instance, over the last four decades, the water salinity level increased about $26 \%$ in the coastal areas of Bangladesh (Alam et al., 2017). This salinity intrusion significantly affected the fertility of coastal areas that act as a barrier in sustainable agriculture that contributes to food security (Islam et al., 2005). An increase in water salinity also changed the physicochemical parameters of the aquatic environments, which ultimately affected the aquatic flora and fauna (Ahmed, 2013). In this case, efficient management of brackish water 
environments is needed to overcome the climate-caused obstacle. It may be necessary to revise the culture practices of salineintolerant species as well as to find innovative techniques for other existing species.

Salinity is among the most important environmental factors that influence the physiological processes of aquatic organisms. Saravanan et al. (2018) reported that fluctuations in salinity greatly influenced the physiology of common carp, Cyprinus carpio. Salinity exposure affected the growth performance of catfish, Clarias gariepinus (Sarma et al., 2013). Fecundity and fertilization and embryonic and larval growth of fish are significantly influenced by water salinity ranges (Boeuf and Payan, 2001; Akitas et al., 2004). Although acclimation of freshwater fish to seawater is species-specific, it is also subject to variation in different developmental stages (Watanabe et al., 1985; Villegas, 1990; Suresh and Lin, 1992). For these reasons, acute salinity tolerance tests in the early stages are of value to forecast the sensitivity of freshwater species (Matern, 2001; Paavola et al., 2005). Embryos and larvae are very sensitive to any changes during all stages of fry production (Akitas et al., 2004; Shahjahan et al., 2017; Rahman et al., 2020; Ashaf-Ud-Doulah et al., 2021).

Striped catfish ( $P$. hypophthalmus) is a popular freshwater aquaculture species. Its growth rate is high and grows well in higher density. Although this fish can survive in a wide range of environmental conditions, its tolerance for osmotic change is limited. For this reason, it should be considered essentially stenohaline in its environmental preferences (Kumar et al., 2017). This air-breathing species might be an important candidate for farming in brackish water on both small and commercial scales. In our previous study, we found better growth performance up to $8 \mathrm{ppt}$ salinity of this fish species in brackish water (Jahan et al., 2019). However, it is important to examine the influence of salinity on embryonic and larval specimens to understand the likelihood of survival, growth, and physiological stability of this species throughout their life cycle in coastal aquaculture systems. A suitable salinity level for the early developmental stages and growth of fish is essential for adaptation in a new saline environment. Although adaptation to saline water is regulated by osmoregulatory mechanisms in different adult fish (Boeuf and Payan, 2001), those adaptive mechanisms may not be available during the early life stages for some fish species (Varsamos et al., 2005; Yang and Chen, 2006; Bodinier et al., 2010). Therefore, this study investigates the effect of variation in salinity on the embryonic and early larval development of striped catfish in a controlled laboratory condition. The present investigations may provide insights into the optimum salinity level for successful egg incubation and early development, which might be helpful to produce fingerlings in brackish water for the sustainable coastal aquaculture of this species.

\section{MATERIALS AND METHODS}

\section{Experimental Animal}

Healthy and active striped catfish ( $P$. hypophthalmus) broods were procured for experimentation from Bangladesh Fisheries
Research Institute (BFRI), Mymensingh, Bangladesh. The average body weights of male and female brood fish were $8.16 \pm 0.68$ and $12.34 \pm 0.44 \mathrm{~kg}$, respectively. The experiment was conducted in compliance with relevant guidelines followed by the Animal and Ethical Committee, Bangladesh Agricultural University (Assent No.: BAU-FoF/2020/004). The legitimate authority of the university approved the study including all the methodologies and fishes for their use for scientific purposes.

\section{Induced Breeding and Fertilization of Eggs}

For induced breeding, two male and two female brood fish were randomly selected. Male and female fish were differentiated by observation of slender genital papillae and swollen abdomens with a reddish color, respectively. They were placed in separate tanks for $6 \mathrm{~h}$ with a mild flow of tap water to induce spawning. Both male and female fish were given intramuscular injection of carp pituitary gland (PG) hormone at dosages of 2 and $6 \mathrm{mg} / \mathrm{kg}$ of body weight, respectively. After injection, both male and female fish were placed in a spawning tank for $8 \mathrm{~h}$. The fish were placed one by one in a plastic bucket for stripping. Male and female were stripped by applying gentle pressure on the abdomen to collect milt and eggs in a plastic bowl. Milt and eggs were mixed thoroughly by using clean and soft poultry feather to accomplish fertilization in well-aerated freshwater.

\section{Experimental Scheme}

Fertilized eggs and larvae were exposed to seven salinity treatments $(0,2,4,6,8,10$, and $12 \mathrm{ppt})$, each with three replications. Natural brine solution containing 260 ppt of salinity was obtained from Marine Fisheries and Technology Station, Cox's Bazar, Bangladesh. To prepare desired concentration of saline water, both brine and dechlorinated tap water were filtered through $65 \mu \mathrm{m}$ of filter paper to remove debris and other suspended solid particles. The different concentrations of test solution were prepared at $0,2,4,6,8,10$, and $12 \mathrm{ppt}$ salinity by adding the required amount of dechlorinated tap water to dilute the stock solution.

\section{Effects of Salinity on Embryonic Stages of Striped Catfish}

Immediately after fertilization, the fertilized eggs were released into previously prepared salinity $(0,2,4,6,8,10$, and $12 \mathrm{ppt}$ )controlled $20 \mathrm{~L}$ aquaria. Eggs were quantified in order to stock the same number into each aquarium, at a density of 100 eggs/20 L water. They were sampled randomly from each aquarium repeatedly from the time of stocking until hatching. Sampled eggs were preserved in $1 \%$ formalin solution in glass vials for immediate observation under a microscope. A minimum of five eggs from each treatment was observed to monitor the effects of salinity on the progress of embryonic development in each set of samples. The effects of salinity were observed using a digital microscope (MCX 100, Micros Austria). Images were obtained using a video-tracking image camera (ModelAmScope1000) connected between microscope and computer. The developmental stages of striped catfish were determined 
according to the developmental stages described by Puvaneswari et al. (2009).

\section{Incubation Period and Hatchability of Striped Catfish}

Distributed fertilized eggs in different salinities $(0,2,4,6,8,10$, and $12 \mathrm{ppt}$ ) were monitored carefully every hour. Dead eggs and anomalies in eggs were recorded and removed immediately to maintain the water quality free from deterioration. After hatching, the early larvae were counted, and hatching rates were calculated in percentages using the following formula:

Hatching rate $=($ No. of hatched fry/No. of fertilized egg) $\times 100$.

\section{Effects of Salinity on the Larval Stages of Striped Catfish}

After hatching in normal (fresh) water, larvae were stocked into seven salinity treatments $(0,2,4,6,8,10$, and $12 \mathrm{ppt})$ at a density of 50 larvae/20 L of water, each with three replications. Aeration was maintained in the aquaria throughout the experimental period. Five larval samples were collected at $12 \mathrm{~h}$ intervals until the completion of yolk sac absorption for microscopic examination as described above.

\section{Determination of the Median Lethal Concentration (LC50) for Embryos and Larvae of Striped Catfish}

Median lethal concentrations for both embryos and larvae were determined at $24 \mathrm{~h}$ intervals. The dead embryos and larvae were collected and recorded from each treatment, and the probit regression analysis was performed using IBM SPSS software version 20.0 (Chicago, IL, United States).

\section{Effect of Salinity on Yolk Sac Absorption}

During the experiment, yolk sac absorption performance was monitored in response to each of the salinity treatments. For this, the samples were taken at early hatching of striped catfish larvae and when the yolk sac was absorbed completely. Then, the yolk sac volume was measured using a digital microscope (MCX 100, Micros Austria). The yolk sac volume and yolk sac absorption were calculated according to Heming and Buddington (1988):

$$
g=\left(\frac{\ln V 0-\ln V t}{t}\right) \times 100 \%
$$

where $g$ is the yolk sac absorption rate, $V_{0}$ is the early volume of the yolk sac $\left(\mathrm{mm}^{3}\right), V_{t}$ is the final volume of the yolk sac $\left(\mathrm{mm}^{3}\right)$, and $t$ is time $(\mathrm{h})$.

\section{Effect of Salinity on $\mathrm{O}_{2}$ Consumption Rate}

Starved 1-day-old larvae (mean length $=4.5 \pm 0.01 \mathrm{~mm}$; mean weight $=0.029 \pm 0.02 \mathrm{mg}$ ) were incubated and hatched at 0,2 , $4,6,8,10$, and $12 \mathrm{ppt}$ salinity in order to estimate the oxygen consumption rates. For this, 20 larvae were randomly collected from each treatment and stocked into each salinity treatment in $200 \mathrm{ml}$ glass bottles. Aeration was provided to maintain the dissolved oxygen saturation, and larvae were allowed to acclimatize the condition for $6 \mathrm{~h}$. After the acclimation period, whole water was exchanged without any disturbance to the larvae, and the bottles were closed. All bottles were maintained under constant illumination and isolation to eliminate external disturbances. Bottles without larvae of each treatment were used as controls. After $48 \mathrm{~h}$ of incubation, larvae were sampled for the measurement of standard and total length. The larvae dry weight was taken $48 \mathrm{~h}$ after holding specimens at $60^{\circ} \mathrm{C}$. The oxygen concentration was determined using Winkler titration method (Strickland and Parsons, 1972):

$$
\mathrm{O}_{2} \text { consumption rate }=1,000 \times V \times \frac{(\text { Oct }- \text { Oex })}{W \times T}
$$

where $V$ is the volume of the bottle, $O_{c t}$ is the control $\mathrm{O}_{2}$ concentrations $\left(\mathrm{mlO}_{2} \mathrm{~L}^{-1}\right), \mathrm{O}_{e x}$ is the experimental $\mathrm{O}_{2}$ concentrations $\left(\mathrm{mlO}_{2} \mathrm{~L}^{-1}\right), W$ is the dry weight of larvae, and $T$ is the incubation time.

\section{Growth Performance Indices}

Different growth performance indices were calculated using the following formula:

1. Yolk consumed (YC) was calculated as follows:

YC (dry weight) $(\mathrm{mg})=$ yolk at hatch (dry weight) - yolk at absorption (dry weight).

2. Yolk sac utilization efficiency:

$$
\mathrm{EP}=\frac{\alpha}{g}
$$

where, $\alpha$ is the long growth rate and $g$ is the yolk sac absorption rate.

3. Length growth rate was determined using the following formula:

$$
\mathrm{LGR}=\frac{(\text { length } f-\text { length } i)}{t}(\mathrm{~mm} / \text { day })
$$

where, length $f$ is the length final and length $i$ is the length initial.

TABLE 1 | Effects of salinity on the incubation period and hatching success of embryos of striped catfish ( $n=300$ embryos).

\begin{tabular}{lccc}
\hline Salinity (ppt) & $\begin{array}{c}\text { Incubation } \\
\text { period (h) }\end{array}$ & $\begin{array}{c}\text { Percentage of dead } \\
\text { embryos at 24 h }\end{array}$ & $\begin{array}{c}\text { Hatching } \\
\text { success (\%) }\end{array}$ \\
\hline 0 & $13.10 \pm 1.6$ & $13.0 \pm 2.2$ & $86.67 \pm 4.23$ \\
2 & $13.55 \pm 2.7$ & $22.0 \pm 1.6$ & $78.00 \pm 7.63$ \\
4 & $14.40 \pm 2.5$ & $28.0 \pm 5.2$ & $71.33 \pm 5.25$ \\
6 & $15.35 \pm 2.3$ & $33.0 \pm 4.6$ & $67.37 \pm 4.34$ \\
8 & $16.10 \pm 3.2$ & $50.0 \pm 3.5^{*}$ & $49.67 \pm 5.61^{*}$ \\
10 & $17.25 \pm 2.1$ & $78.7 \pm 4.0^{*}$ & $21.27 \pm 3.17^{*}$ \\
12 & - & $100.0 \pm 0.0^{*}$ & $00.00 \pm 0.00$ \\
LC50 value & 11.24 & & \\
\hline
\end{tabular}

*Significance level $(p<0.05)$. 


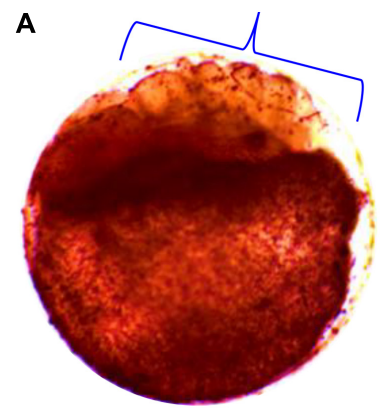

D

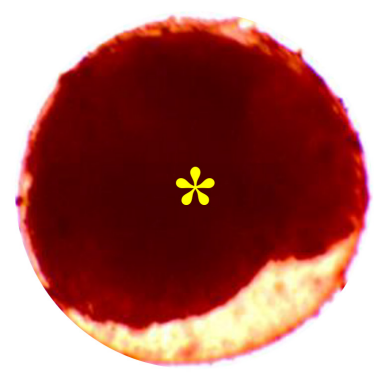

G

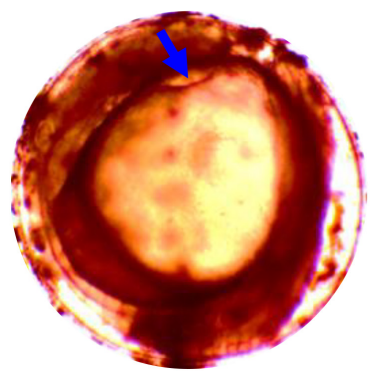

B

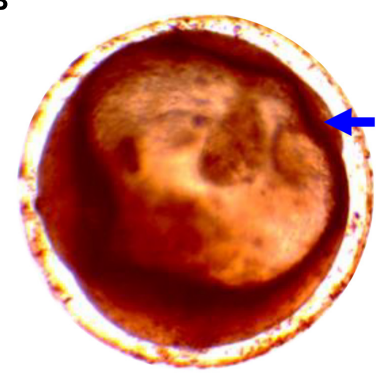

E

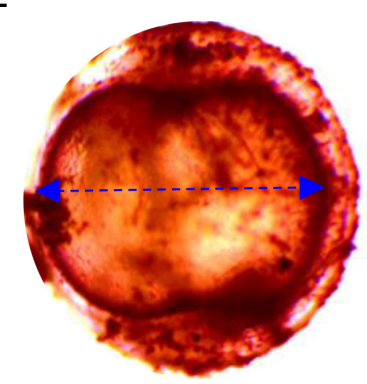

H

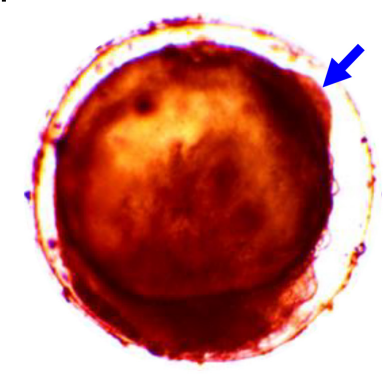

C

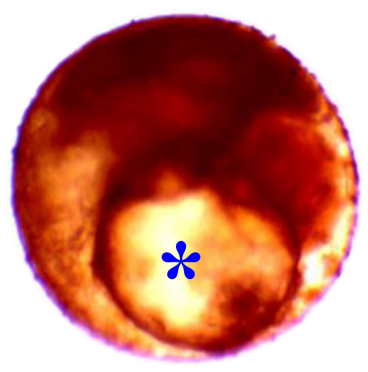

$\mathbf{F}$

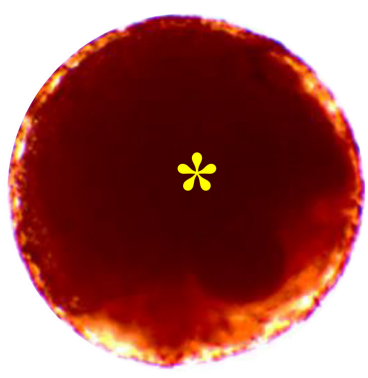

I

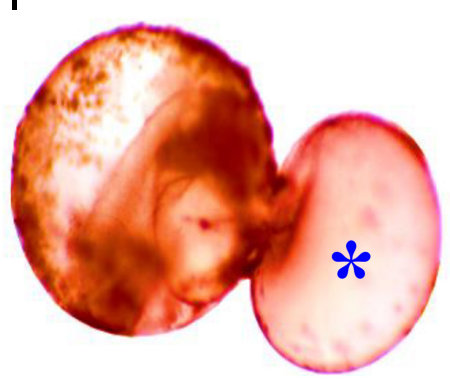

FIGURE 1 | Deformities in embryos of striped catfish exposed to different salinities; (A) cell deformities and damaged at 6 ppt salinity after1 $\mathrm{h} 47 \mathrm{~min}$, (B) no detachment of tail at 8 ppt salinity after $3 \mathrm{~h}$ (arrow), (C) undeveloped yolk sac at 10 ppt salinity after $3 \mathrm{~h} 58$ min (asterisk), (D) coagulated embryo in glyphosate at 10 ppt salinity after $12 \mathrm{~h} 48 \mathrm{~min}$ (asterisk), (E) gastrula yolk sac elongated shape and lack of heartbeat at 4 ppt salinity after $15 \mathrm{~h} 15 \mathrm{~min}$ (arrow line), (F) agglutination of the embryo at 4 ppt salinity after $18 \mathrm{~h} 10 \mathrm{~min}$ (asterisk), (G) streaks within the chorion at 6 ppt salinity after $15 \mathrm{~h} 15 \mathrm{~min}$ (arrow), (H) cleavage yolk sac bud/snowball at 6 ppt salinity after 16 h 15 min (arrow), and (I) embryos swelling/pustule at 8 ppt salinity after $27 \mathrm{~h} 35 \mathrm{~min}$ (asterisk). Scale bar $=40 \mu \mathrm{m}$.

4. Weight growth rate was determined using the following formula:

$$
\mathrm{WGR}=\frac{w t \mathrm{f}-\mathrm{wt} i}{t}(m g / \text { day })
$$

where, wt $f$ is the weight final and wt $i$ is the weight initial.

5. Developmental index was expressed as $\mathrm{KD}=10$ (wet $\left.\mathrm{wt}^{1 / 3}\right)$ /length.

\section{Data Analysis}

For statistical analysis, all data were collected and noted carefully in the Microsoft Excel Worksheet 2010 during the whole experimental period. All analyzed data were exhibited as mean \pm standard deviation (SD). One-way analysis of variance
(ANOVA) was used followed by Tukey's test to analyze data for checking statistical significant difference among different salinity groups. The significant level of $p<0.05$ value (SPSS version 20.0 for windows SPSS Inc., Chicago, IL, United States) was used to perform all the statistical analyses.

\section{RESULTS}

\section{Effect of Salinity on Embryonic Development of Striped Catfish}

Considerable survivability of embryos was recorded at up to $6 \mathrm{ppt}$ salinity. Mortality of embryos significantly $(p<0.05)$ increased at 8 and 10 ppt salinity, and $100 \%$ mortality was displayed at 
12 ppt salinity within $12 \mathrm{~h}$ of exposure (Table 1 ). Similarly, the rate of hatching success was significantly reduced $(p<0.05)$ at 8 and 10 ppt salinity (Table 1 ). The incubation period depends on the salinity and incubation duration increased with increasing salinity (Table 1). The $24 \mathrm{~h} \mathrm{LC50}$ value of salinity for the embryo was 11.24 ppt. Different types of deformities, such as damaged cell, undeveloped yolk sac, coagulated embryo in glyphosate, elongated gastrula yolk sac, streaks within the chorion, and yolk sac bud, were recorded in embryos at different time intervals in response to different salinities (Figure 1). The highest rate of deformities of embryos was recorded at 10 ppt salinity (Table 2).

\section{Effect of Salinity on the Larval Development of Striped Catfish}

Similar to the embryo, substantial survivability of larvae was observed up to $6 \mathrm{ppt}$ salinity. Larval mortality increased significantly $(p<0.05)$ at and above 6 ppt salinity, and $100 \%$ mortalities were found within $24 \mathrm{~h}$ of exposure at $12 \mathrm{ppt}$ salinity (Table 3). The 24 and $48 \mathrm{~h} \mathrm{LC50} \mathrm{values} \mathrm{of} \mathrm{salinity} \mathrm{for} \mathrm{larvae}$ were 10.63 and $8.48 \mathrm{ppt}$, respectively. Several types of deformities, including yolk sac ulceration, the bent axis in either direction, impairment of swim bladder inflation, pericardial edema, spine scoliosis, tail bent, and yolk sac edema, were observed in larvae at different time intervals in different salinities (Figure 2). The rate of larval abnormalities was significantly $(p<0.05)$ increased in response to increasing salinity after 24 and $48 \mathrm{~h}$ of exposure (Table 4). In response to the control condition, larvae exhibited no larval deformities. The highest percentage of deformities was recorded at $10 \mathrm{ppt}$ salinity after $48 \mathrm{~h}$ of exposure.

\section{Effect of Salinity on Yolk Sac Absorption, Yolk Sac Utilization Efficiency, and $\mathrm{O}_{2}$ Consumption of Larvae of Striped Catfish}

Yolk sac absorption, yolk sac utilization efficiency, and $\mathrm{O}_{2}$ consumption of larvae of striped catfish exposed to different salinities are shown in Table 5. Rapidly increasing yolk sac absorption rates (\%) were observed at increasing salinity. Within $24 \mathrm{~h}$ of exposure, about $80 \%$ of the larval yolk sac was absorbed at 8 and $10 \mathrm{ppt}$ salinity, while $30-50 \%$ yolk sac was absorbed at $0-6$ ppt salinity. As a result, weight at yolk sac absorption $(\mathrm{mg})$ of the larvae was significantly $(p<0.05)$ highest at $10 \mathrm{ppt}$ salinity. Accordingly, significantly $(p<0.05)$ higher yolk sac absorption efficiency was recorded at $0,2,4$, and 6 ppt salinity. After $48 \mathrm{~h}$ of exposure, the highest larval $\mathrm{O}_{2}$ consumption $(p<0.05)$ was observed at 8 and 10 ppt salinity, in comparison with controls (Table 5).

\section{Effects of Salinity on the Length Growth Rate, Weight Growth Rate, and Developmental Index of Larvae of Striped Catfish}

Length growth rate (LGR), weight growth rate (WGR), and developmental index (KD) of larvae of striped catfish exposed to different salinities are presented in Table 6. Significantly $(p<0.05)$ higher LGR and WGR were recorded at 0,2 , and 4 ppt salinity. Moderate LGR and WGR were observed at 6 and 8 ppt salinity, whereas significantly $(p<0.05)$ reduced LGR and WGR were found at $10 \mathrm{ppt}$ salinity. The KD was significantly $(p<0.05)$ highest at 10 ppt salinity, whereas significantly $(p<0.05)$ lowest $\mathrm{KD}$ was observed in control specimens.

\section{DISCUSSION}

The salinity tolerance test among newly hatched larvae reveals an important determinant of the likelihood of successful introduction of freshwater species in estuarine environments (Boeuf and Payan, 2001; Matern, 2001; Paavola et al., 2005). This study demonstrated considerable survivability and hatching success of embryos at up to 6 ppt salinity with a 24 h LC50 value of 11.24 ppt salinity. The embryo of some strains of Nile tilapia can tolerate up to $20 \mathrm{ppt}$ salinity (despite reductions in hatching success; Fridman et al., 2012), which exceeds the tolerance rate seen in this study. The $24 \mathrm{~h}$ LC50 value of salinity for the embryo of a freshwater aquaculture species pabda, Ompok pabda, was 15.07 ppt with lower hatching success (Alam et al., 2020), which is higher than the tolerance rate seen in this study. In another study, reduced hatching success was recorded in different salinities $(0,5$, $10,15,20,25$, and $32 \mathrm{ppt}$ ) after the transfer of freshwater spawned eggs of Nile tilapia, Oreochromis niloticus (Watanabe et al., 1985). However, mortality of embryos significantly increased at 8 and 10 ppt salinity, and $100 \%$ mortality was displayed after $12 \mathrm{~h}$

TABLE 2 | Percent (\%) abnormalities of the embryo of striped catfish in different salinities ( $n=150$ embryos).

\begin{tabular}{lccc}
\hline Salinity (ppt) & \multicolumn{3}{c}{ Exposure period (hours) } \\
\cline { 2 - 4 } & $\mathbf{1 2}$ & $\mathbf{2 4}$ & $\mathbf{3 6}$ \\
\hline 0 & 0 & $3.0 \pm 0.08$ & $2.0 \pm 0.09$ \\
2 & $3.0 \pm 0.05$ & $5.0 \pm 0.02$ & $5.0 \pm 0.06$ \\
4 & $4.0 \pm 0.07$ & $6.0 \pm 0.11$ & $7.0 \pm 0.02$ \\
6 & $2.0 \pm 0.03$ & $8.0 \pm 0.07$ & $13.0 \pm 0.10^{*}$ \\
8 & $5.0 \pm 0.11$ & $12.0 \pm 0.05^{\star}$ & $16.0 \pm 0.07^{*}$ \\
10 & $8.0 \pm 0.09^{*}$ & $13.0 \pm 0.03^{\star}$ & $16.0 \pm 0.04^{*}$ \\
12 & All embryos died within $12 \mathrm{~h}$ & \\
\hline
\end{tabular}

*Significance level $(p<0.05)$.

TABLE 3 | Effects of salinity on larval mortality of striped catfish ( $n=150$ larvae).

\begin{tabular}{lcc}
\hline Salinity (ppt) & $\begin{array}{c}\text { Percentage of dead } \\
\text { larvae at } \mathbf{2 4} \mathbf{~ h}\end{array}$ & $\begin{array}{c}\text { Percentage of dead } \\
\text { larvae at } \mathbf{4 8 ~} \mathbf{~ h}\end{array}$ \\
\hline 0 & $8.0 \pm 0.6$ & $15.0 \pm 0.6$ \\
2 & $2.0 \pm 1.6$ & $7.0 \pm 1.6$ \\
4 & $14.0 \pm 4.0$ & $35.0 \pm 4.0$ \\
6 & $22.0 \pm 4.6^{\star}$ & $45.0 \pm 4.6^{\star}$ \\
8 & $36.0 \pm 7.6^{\star}$ & $67.0 \pm 7.6^{\star}$ \\
10 & $52.0 \pm 1.4^{*}$ & $78.0 \pm 1.4^{\star}$ \\
12 & $100.0 \pm 0.0^{\star}$ & $100.0 \pm 0.0^{\star}$ \\
LC50 value & 10.63 & 8.48 \\
\hline
\end{tabular}

*Significance level $(p<0.05)$. 


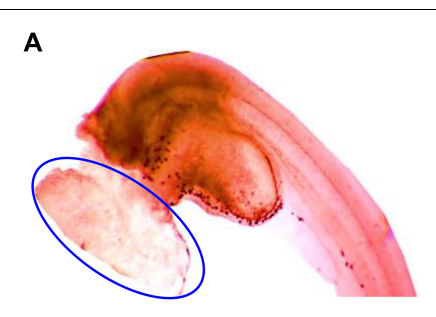

B

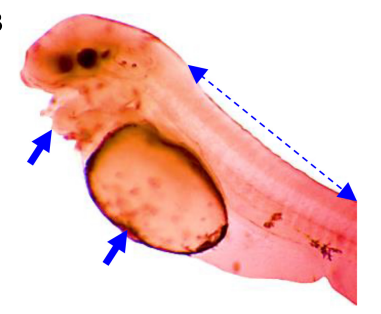

D

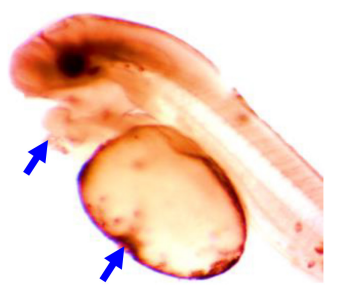

$\mathbf{G}$
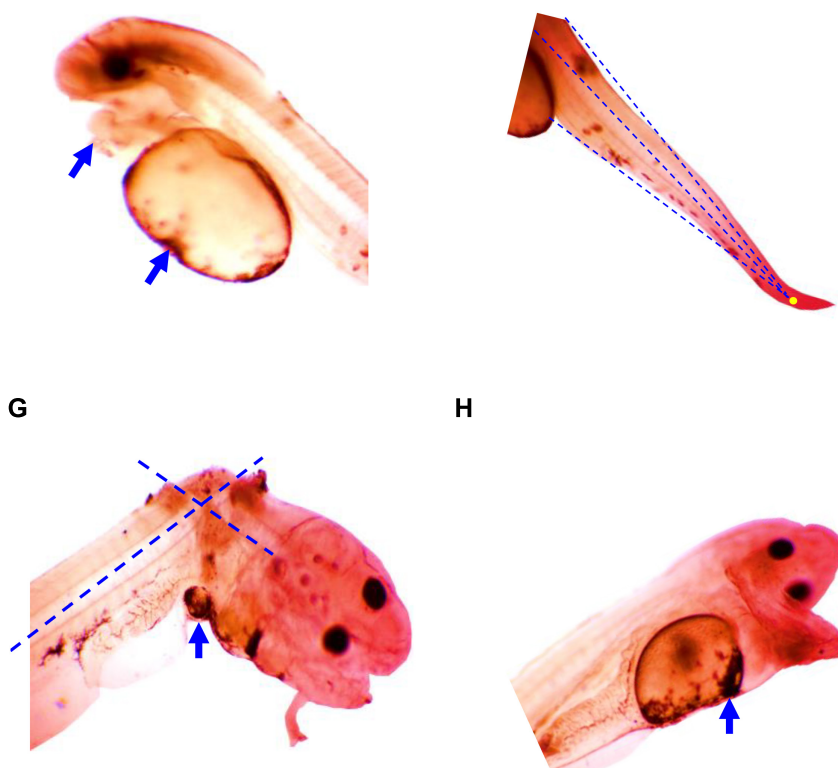

H
C
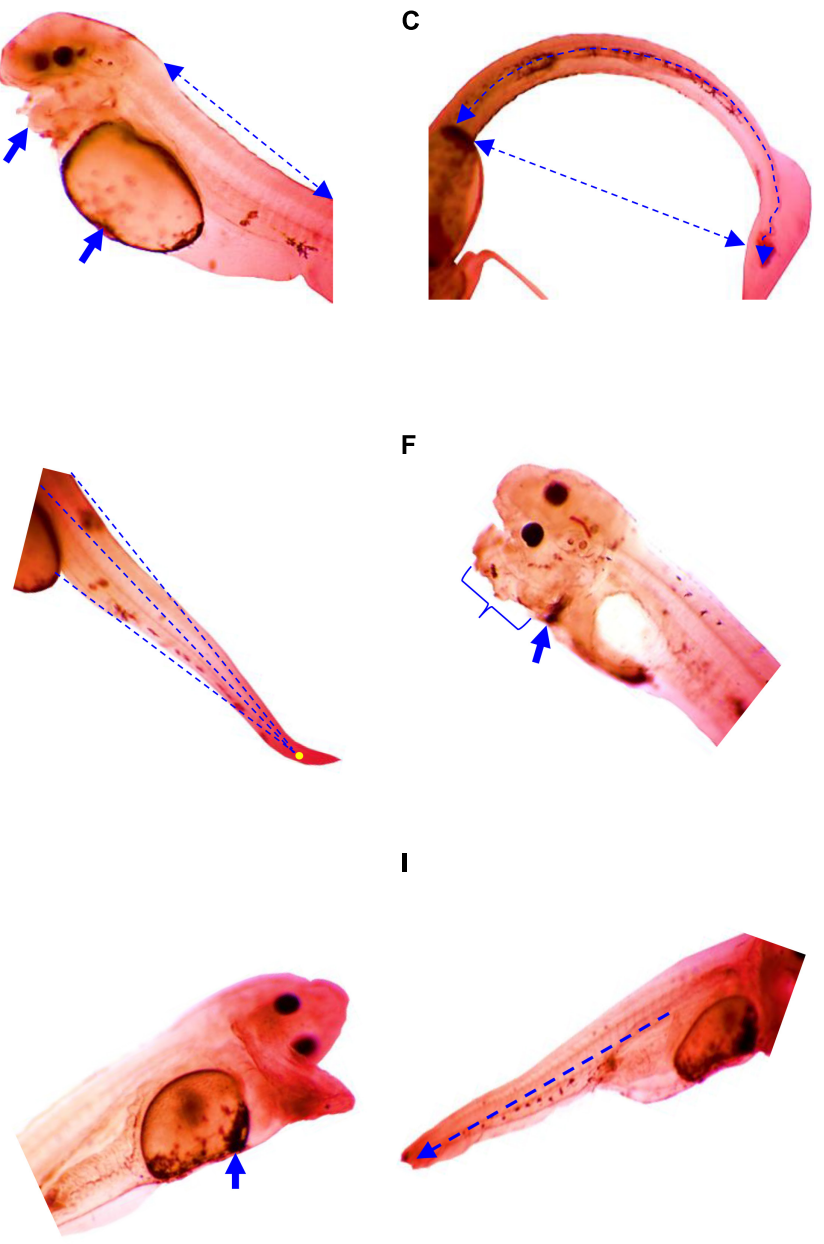

F

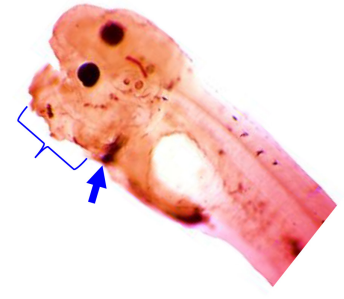

I

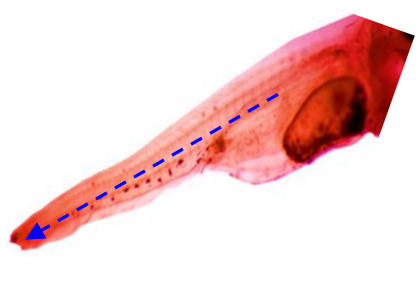

FIGURE 2 | Deformities in larvae of striped catfish exposed to different salinities; (A) yolk sac ulceration, anterior curve at 6 ppt salinity after 8 h 40 min, (B) axis-curve or bent axis in either direction (arrow line), swim bladder inflate, pericardial edema at 10 ppt salinity after 15 h 45 min (arrow), (C) spine scoliosis at 6 ppt salinity after $17 \mathrm{~h} 30 \mathrm{~min}$ (arrow curve), (D) pericardial malformation at 4 ppt salinity after $18 \mathrm{~h}$ (arrow), (E) notochord curve and tail bent at 10 ppt salinity $27 \mathrm{~h}$ 25 min, (F) jaw and pericardial edema at 4 ppt salinity after 27 h 40 min (arrow), (G) stretched heart, pericardial edema at 8 ppt salinity after 36 h 25 min, (H) yolk sac edema at 10 ppt salinity after $43 \mathrm{~h} 35 \mathrm{~min}$ (arrow), and (I) shortage end tail at 6 ppt salinity after $44 \mathrm{~h} 50 \mathrm{~min}$ (arrow line). Scale bar = $50 \mu \mathrm{m}$.

of exposure to an ambient 12 ppt salinity. Higher mortalities in higher salinities might be due to changes in the osmotic and ionic influences of water on eggs and embryos (Alderdice, 1988). Limited tolerance for higher salinity is a characteristic of closely related adult pangas fish, such as Pangasius hypothalamus. This species displays higher growth rates and lower mortality rates in freshwater than in brackish water (Mandal et al., 2017). We observed various ontogenetic deformities during early development, such as damaged cells, undeveloped yolk sac, coagulated embryo in glyphosate, elongated gastrula yolk sac, streaks within the chorion, and yolk sac bud, were maximal in response to $10 \mathrm{ppt}$ salinity in this study. Even slight variation from optimal salinity can induce extensive deformities, reflecting osmoregulatory challenges encountered by embryos at higher salinity (Cook et al., 2005; Brown et al., 2010; Ekrem et al., 2012; Hayes et al., 2014). In the aquatic environment, salinity has huge influences on the cellular stability of an organism. Thus, osmotic pressure was changed in case of need for a huge amount of energy.
As a result, cellular anomalies and cellular death occurred within the body of the organism (Cañedo-Argüelles et al., 2019).

Higher rates of survival of larvae of striped catfish were recorded up to $6 \mathrm{ppt}$ salinity, although 100\% mortalities were found at $12 \mathrm{ppt}$ salinity within $24 \mathrm{~h}$ of exposure. The 24 and $48 \mathrm{~h}$ LC50 values of salinity for larvae exhibited at 10.63 and $8.48 \mathrm{ppt}$ salinity, respectively. Higher mortalities in higher salinity might be due to an inability to adapt to osmoregulatory challenges just after hatching and an insufficient capacity to maintain ionic and osmotic balance during the yolk sac period. Salinity plays a significant role in freshwater aquatic organisms to regulate the osmotic stability among ion concentrations and internal body fluids (Cañedo-Argüelles et al., 2019). As salinity enhances osmotic pressure, consequently, it has adverse effects on the body fitness and survivability of the organisms. The living organism in the freshwater aquatic environment requires an osmotic balance between ion concentrations and fluids within the body cells. Thus, salt ions producing toxicity have direct negative impacts 
TABLE 4 | Percent (\%) abnormalities of larvae of striped catfish in different salinities ( $n=150$ larvae).

\begin{tabular}{lcc}
\hline Salinity (ppt) & \multicolumn{2}{c}{ Exposure period (hours) } \\
\cline { 2 - 3 } & $\mathbf{2 4}$ & $\mathbf{4 8}$ \\
\hline 0 & 0 & 0 \\
2 & $3.0 \pm 0.05$ & $7.0 \pm 0.09$ \\
4 & $5.0 \pm 0.09$ & $9.0 \pm 0.04$ \\
6 & $8.0 \pm 0.02$ & $11.0 \pm 0.03$ \\
8 & $11.0 \pm 0.07^{*}$ & $13.0 \pm 0.04^{*}$ \\
10 & $12.0 \pm 0.01^{*}$ & $14.0 \pm 0.07^{*}$ \\
12 & All larvae died within $18 \mathrm{~h}$ & \\
\hline
\end{tabular}

*Significance level $(p<0.05)$.

not only on physiology of the individual species but also on species population (Nielsen et al., 2003).

Salinity adaptation in fully euryhaline species is reliant on the gene expression of compounds that are involved directly and indirectly in ion transport (Lee et al., 2020; Bonzi et al., 2021). A comparison of closely related medaka species revealed a relationship of cotransporter gene expression with the ability to tolerate osmotic challenges (Juo et al., 2016). Some selection favoring morphological change has been associated with the tolerance of variable osmotic conditions in the genus Fundulus (Styga et al., 2019).

However, some fish larval strains and species can maintain ionic and osmotic balance between their internal and external environments during their yolk sac stages (Alderdice, 1988; Kaneko et al., 1995), which is consistent with the survivability of the larvae exposed to salinity up to $6 \mathrm{ppt}$ in this study. For instance, the larvae of the marine rabbit fish, Siganus guttatus can tolerate $14-37$ ppt salinity range after transfer from 10 to $45 \mathrm{ppt}$ salinity (Young and Dueñas, 1993). This species is known to be at least semi-euryhaline, inhabiting marine and estuarine waters and occasionally rivers as adults (Food Agriculture Organization [FAO], 2021). Likewise, a longer LC50 was recorded for the red snapper, Lutjanus argentimaculatus, larvae in lower salinity when transferred from 32 ppt salinity (Estudillo et al., 2000). In this study, several types of deformities including yolk sac ulceration, axis-curve or bent axis in either direction, swim bladder inflate, spine scoliosis, tail bent, and yolk sac edema were increased in response to an increase in salinity after 24 and $48 \mathrm{~h}$ of exposure.
TABLE 6 | Effects of salinity on length growth rate (LGR), weight growth rate (WGR), and developmental index (KD) of larvae of striped catfish ( $n=150$ larvae).

\begin{tabular}{lccc}
\hline Salinity & LGR (mm/day) & WGR $(\mathbf{m g} /$ day) & KD \\
\hline 0 & $0.625 \pm 0.07^{b}$ & $0.100 \pm 0.006^{b}$ & $0.167 \pm 0.03^{a}$ \\
2 & $0.575 \pm 0.03^{b}$ & $0.087 \pm 0.007^{b}$ & $0.170 \pm 0.02^{a}$ \\
4 & $0.425 \pm 0.02^{b}$ & $0.062 \pm 0.005^{b}$ & $0.184 \pm 0.04^{a b}$ \\
6 & $0.325 \pm 0.05^{a b}$ & $0.037 \pm 0.002^{a b}$ & $0.197 \pm 0.07^{a b}$ \\
8 & $0.250 \pm 0.04^{a b}$ & $0.025 \pm 0.004^{a}$ & $0.205 \pm 0.02^{b}$ \\
10 & $0.125 \pm 0.02^{a}$ & $0.018 \pm 0.003^{a}$ & $0.223 \pm 0.01^{b}$ \\
12 & All larvae died within 18 h & \\
\hline Values in a column with different alphabetical superscripts & are significantly \\
$(p<0.05)$ different among treatments. &
\end{tabular}

In addition, ulceration of the yolk sac occurred tremendously as this is the early stage of hatching. This stage is exceedingly sensitive to environmental factors as well as toxic elements. In our previous studies, we observed similar findings that yolk sac ulceration occurred in rohu, Labeo rohita, due to the effect of temperature (Ashaf-Ud-Doulah et al., 2021) and ulceration of yolk sac in zebrafish, Danio rerio, caused by sumithion (Rahman et al., 2020). Likewise, several researchers exhibited yolk sac edema in African catfish, C. gariepinus (Marimuthu et al., 2013); yolk sac malformation in Nile tilapia, Oreochromis niloticus (El-Greisy et al., 2016); yolk sac deformities in zebrafish, Danio rerio (Zoupa and Machera, 2017) in their previous experiment. However, all of these deformities are probably due to complications faced by embryos adapting to osmoregulatory challenges in different salinities (Ekrem et al., 2012; Hayes et al., 2014). Similar responses to salinity including higher mortality, slower development, and a variety of abnormalities have been observed in the larvae of Nile tilapia (Fridman et al., 2012), catfish, C. gariepinus (Jomori et al., 2012) and pabda, O. pabda (Alam et al., 2020). Some recent investigation suggests that alterations in transepithelial potential (TEP) may serve in a signaling capacity during osmotic acclimation or recovery from injury (Kennard and Theriot, 2020).

The increased survivability of larvae of striped catfish at up to $6 \mathrm{ppt}$ salinity probably reflects an increase in the numbers of chloride cells and development of the branchial system, both of which help to address the osmoregulatory challenge. It has been reported that the first appearance of branchial chloride cells was observed at 8 days post-hatch in Japanese flounder, Paralichthys

TABLE 5 | Yolk sac absorption (\%), weight of yolk sac absorption (mg), yolk sac utilization efficiency, and $\mathrm{O}_{2}$ consumption (ml $\mathrm{O}_{2} \mathrm{~g}^{-1} \mathrm{dry}_{\text {weight }} \mathrm{h}^{-1}$ ) of striped catfish larvae in different salinities.

\begin{tabular}{|c|c|c|c|c|}
\hline Salinity & Yolk sac absorption (\%) at $24 \mathrm{~h}$ & Weight of yolk sac absorption (mg) & Yolk sac utilization efficiency & $\mathrm{O}_{2}$ consumption at $48 \mathrm{~h}$ \\
\hline 0 & $30.0 \pm 2.02^{\mathrm{a}}$ & $0.40 \pm 0.06^{\mathrm{a}}$ & $1.563 \pm 0.03^{c}$ & $1.070 \pm 0.02^{\mathrm{a}}$ \\
\hline 2 & $37.0 \pm 2.07^{a}$ & $0.40 \pm 0.04^{a}$ & $1.436 \pm 0.04^{c}$ & $1.265 \pm 0.05^{a b}$ \\
\hline 4 & $42.0 \pm 3.10^{a b}$ & $0.45 \pm 0.07^{a b}$ & $0.945 \pm 0.06^{b}$ & $1.359 \pm 0.06^{a b}$ \\
\hline 6 & $50.0 \pm 3.03^{a b}$ & $0.45 \pm 0.04^{a b}$ & $0.722 \pm 0.02^{b}$ & $1.290 \pm 0.07^{a b}$ \\
\hline 8 & $78.0 \pm 2.11^{b}$ & $0.45 \pm 0.03^{a b}$ & $0.556 \pm 0.07^{a b}$ & $1.431 \pm 0.09^{b}$ \\
\hline 10 & $81.0 \pm 4.12^{b}$ & $0.50 \pm 0.11^{b}$ & $0.250 \pm 0.06^{a}$ & $1.453 \pm 0.01^{b}$ \\
\hline 12 & All larvae died within $18 \mathrm{~h}$ & & & \\
\hline
\end{tabular}

Values in a column with different alphabetical superscripts are significantly $(p<0.05)$ different among treatments. 
olivaceus (Hiroi et al., 1998). Li et al. (1995) identified chloride cells on branchial epithelia during yolk sac stages in Mozambique tilapia, Oreochromis mossambicus. These chloride cells are also observed in the membrane of the yolk sac as well as other body surfaces of embryos and larvae. However, it is assumed that the generalization of extrabranchial chloride cells poses a central crucial role in osmoregulation until the gill chloride cells to be functional (Kaneko et al., 2002). During ontogeny, a distinct shift in ionocyte from the body surface to branchial areas has been reported in the killifish, Fundulus hereroclitus (Katoh et al., 2000), the European sea bass, Dicentrarchus labrax (Varsamos et al., 2002), the Mozambique tilapia (Yanagie et al., 2009), and the Nile tilapia (Fridman et al., 2011). Salinity adaptations not only increase in the abundance of chloride cells but also require intracellular redistribution of ion transport molecules (i.e., Na+/K+-ATPase; McCormick et al., 2003). These ion transport molecules assist to regulate the osmotic steadiness and membrane potential in the cells (Geering, 2008; Kopec et al., 2014). The sodium and potassium move against the concentration gradients. The $\mathrm{Na}+\mathrm{K}+$-ATPase pump maintains the gradient of a higher concentration of extracellular sodium and a higher level of intracellular potassium (Pivovarov et al., 2018). Normally kidney used this sodium gradient to regulate the $\mathrm{pH}$ and electrolyte levels in the blood, reabsorptions of amino acids and glucose, and overall filtering the waste product in the blood (El Mernissi et al., 1991).

The rate of oxygen consumption has served as an indicator of metabolism in fish (Cech, 1990). In this study, $\mathrm{O}_{2}$ consumption of larvae was found significantly highest at 8 and $10 \mathrm{ppt}$ salinity. This is might be due to higher metabolic rates and additional physiological stress at non-isosmotic salinity, increasing osmoregulatory costs and oxygen demand. Oxygen consumption rates were increased with increasing salinity during the yolk sac period in $O$. niloticus, the Nile tilapia (Fridman et al., 2012). Similar results have been reported for juvenile and adult sea bream, Sparus sarba (Woo and Kelly, 1995) and O. mossambicus x Oreochromis hornorum hybrids (Febry and Lutz, 1987). Moreover, metabolic rates are strongly influenced by the developmental stage (Swanson, 1996). Linear relationships between age during embryogenesis and oxygen consumption have been recorded in common carp, C. carpio (Kaushik et al., 1982), striped mullet, Mugil cephalus (Walsh and Lund, 1989), and milkfish, Chanos Febri (Swanson, 1996).

In this study, within 24 h of exposure, about $80 \%$ of the larval yolk sac was absorbed at 8 and 10 ppt salinity, while $30-50 \%$ yolk sac was absorbed at 0-6 ppt salinity. Accordingly, significantly higher yolk sac absorption efficiency was recorded at 0, 2, 4, and 6 ppt salinity. This might be due to energy consumption in response to the osmoregulatory challenge just after hatching and to the need of maintaining ionic and osmotic balance during the yolk sac period. Yolk serves as the initial energy source for larvae,

\section{REFERENCES}

Ahmed, N. (2013). Linking prawn and shrimp farming towards a green economy in Bangladesh: confronting climate change. Ocean Coast Manag. 75, 33-42. doi: 10.1016/j.ocecoaman.2013.01.002 providing protein and free amino acids required for the early development (Dabrowski, 1983; Conceição et al., 1997). Overall, significantly higher LGR and WGR of larvae of striped catfish at 0,2 , and 4 ppt salinity, and moderate but tolerable LGR and WGR at 6 and 8 ppt salinity in this study, warrant the striped catfish as recommended candidates for coastal aquaculture.

\section{CONCLUSION}

In conclusion, for introducing a species in coastal areas, a suitable environmental salinity level is essential for the early development and growth of fish larvae. This study has been conducted and provides detailed information about the embryonic and larval development of striped catfish in different salinity concentrations. The present findings provide useful information on salinity effects on the early life development of striped catfish. The results of this study make species candidates for larval rearing in controlled conditions for restocking purposes. The results of this study have important practical implications for handling the hatchery production method properly and for the future potential for aquaculture of this species in brackish water.

\section{DATA AVAILABILITY STATEMENT}

The raw data supporting the conclusions of this article will be made available by the authors, without undue reservation.

\section{ETHICS STATEMENT}

The animal study was reviewed and approved by the Animal and Ethical Committee, Bangladesh Agricultural University.

\section{AUTHOR CONTRIBUTIONS}

FH performed the experiment, data collection, and drafting of the manuscript. SI and MA-U-D assisted in the data collection and analysis. MA facilitated the brood fish to get embryos and larvae. MI and CB edited the manuscript. MS conceived, designed, supervised, and analyzed the data, and edited the manuscript. All authors reviewed and approved the final manuscript.

\section{ACKNOWLEDGMENTS}

National Agricultural Technology Project, Phase-II (20192022) is gratefully acknowledged for providing a Ph.D. fellowship to FH.

Akitas, M., Eroldogan, T., and Kumlu, M. (2004). Combined effects of temperature and salinity on egg hatching rates and incubation time of Penaeus semisulcatus (Decapoda: Penaeidae). Isr. J. Aquacult. 56, 124-128.

Alam, M. R., Sharmin, S., Islam, S. M. M., Alam, M. A., Ehiguese, F. O., Pattadar, S. N., et al. (2020). Salinity intrusion affects early development of freshwater 
aquaculture species pabda, Ompok pabda. Aquacult. Rep. 18:100476. doi: 10. 1016/j.aqrep.2020.100476

Alam, M. Z., Carpenter-Boggs, L., Mitra, S., Haque, M., Halsey, J., Rokonuzzaman, M., et al. (2017). Effect of salinity intrusion on food crops, livestock, and fish species at Kalapara coastal belt in Bangladesh. J. Food Qual. 2017:204 5157.

Alderdice, D. F. (1988). "Osmotic and ionic regulation in teleost eggs and larvae," in Fish Physiology, Vol. XIA, eds W. S. Hoar and D. J. Randall (New York, NY: Academic Press), 163-251. doi: 10.1016/s1546-5098(08)60200-9

Ashaf-Ud-Doulah, M., Islam, S. M. M., Zahangir, M. M., Islam, M. S., Brown, C., and Shahjahan, M. (2021). Increased water temperature interrupts embryonic and larval development of Indian major carp rohu Labeo rohita. Aquacult. Int. 29, 711-722. doi: 10.1007/s10499-021-00649-x

Bodinier, C., Sucré, E., and Lecurieux-Belfond, L. (2010). Ontogeny of osmoregulation and salinity tolerance in the gilthead sea bream Sparus aurata. Comp. Biochem. Physiol. A Mol. Integr. Physiol. 157, 220-228. doi: 10.1016/j. cbpa.2010.06.185

Boeuf, G., and Payan, P. (2001). How should salinity influence fish growth? Comp. Biochem. Physiol. C Toxicol. Pharmacol. 130, 411-423. doi: 10.1016/s15320456(01)00268-x

Bonzi, L. C., Monroe, A. A., Lehmann, R., Berumen, M. L., Ravasi, T., and Schunter, C. (2021). The time course of molecular acclimation to seawater in a euryhaline fish. Sci. Rep. 11:18127. doi: 10.1038/s41598-021-97295-3

Brown, C. L., Power, D. M., and Núñez, J. M. (2010). "Disorders of development in fish," in Fish disease and disorders, volume 2. Non-Infectious Disorders, 2nd Edn, eds J. K. Leatherland and P. T. K. Woo (Wallingford: CAB International Press), 166-182. doi: 10.1079/9781845935535.0166

Cañedo-Argüelles, M., Kefford, B., and Schäfer, R. (2019). Salt in freshwaters: causes, effects and prospects - introduction to the theme issue. Philos. Trans. R. Soc. B Biol. Sci. 374:20180002. doi: 10.1098/rstb.2018.0002

Cech, J. J. (1990). "Respirometry," in Methods for Fish Biology, eds C. B. Schreck and P. B. Moyle (Bethseda, MD: American Fisheries Society), 335-365.

Conceição, L. E. C., Van der Meeren, T., and Verreth, J. A. J. (1997). Amino acid metabolism and protein turnover in larval turbot (Scophthalmus maximus) fed natural zooplankton or artemia. Mar. Biol. 129, 255-265. doi: 10.1007/ s002270050166

Cook, L. W., Paradise, C. J., and Lom, B. (2005). The pesticide malathion reduces survival and growth in developing zebrafish. Environ. Toxicol. Chem. 24, 1745-1750. doi: 10.1897/04-331r.1

Dabrowski, K. (1983). Comparative aspects of protein digestion and amino acid absorption in fish and other animals. Comp. Biochem. Physiol. 74, 417-425. doi: 10.1016/0300-9629(83)90625-4

Ekrem, S. C., Hasan, K., and Sevdan, Y. (2012). Effects of phosalone on mineral contents and spinal deformities in common carp (Cyprinus carpio L.1758). Turk. J. Fish. Aquat. Sci. 12, 259-264.

El Mernissi, G., Barlet-Bas, C., Khadouri, C., Marsy, S., Cheval, L., and Doucet, A. (1991). Characterization and localization of ouabain-insensitive Na-dependent ATPase activities along the rat nephron. Biochim. Biophys. Acta 1064, 205-211. doi: 10.1016/0005-2736(91)90303-p

El-Greisy, Z. A. E., Elgamal, A. E. E., and Nasr Ahmed Mohamed Ahmed, N. A. A. (2016). Effect of prolonged ammonia toxicity on fertilizedeggs, hatchability and size of newly hatched larvaeof Nile tilapia, Oreochromis niloticus. Egypt. J. Aquat. Res. 42, 215-222. doi: 10.1016/j.ejar.2016.04.001

Estudillo, C. B., Duray, M. N., Marasigan, E. T., and Emata, A. C. (2000). Salinity tolerance of larvae of the mangrove red snapper (Lutjanus argentimaculatus) during ontogeny. Aquaculture 190, 155-167. doi: 10.1016/s0044-8486(00) 00390-2

Febry, R., and Lutz, P. (1987). Energy partitioning in fish: the activity related cost of osmoregulation in a euryhaline cichlid. J. Exp. Biol. 128, 63-85. doi: 10.1242/jeb.128.1.63

Food Agriculture Organization [FAO] (2021). Cultured Aquatic Species Information Programme. Siganus spp. Cultured Aquatic Species Information Programme. Rome: FAO.

Fridman, S., Bron, J. E., and Rana, K. J. (2011). Ontogenetic changes in location and morphology of chloride cells during early life stages of the Nile tilapia Oreochromis niloticus adapted to fresh and brackish water. J. Fish Biol. 79, 597-614. doi: 10.1111/j.1095-8649.2011.03043.x
Fridman, S., Bron, J. E., and Rana, K. J. (2012). Influence of salinity on embryogenesis, survival, growth and oxygen consumption in embryos and yolk-sac larvae of the Nile tilapia. Aquaculture 334-337, 182-190.

Geering, K. (2008). Functional roles of Na,K-ATPase subunits. Curr. Opin. Nephrol. Hypertens. 17, 526-532. doi: 10.1097/mnh.0b013e3283036cbf

Hayes, M., Xiaochong, G., Lisa, X. Y., Nandina, P., Henkelman, R. M., Carol, A. W., et al. (2014). ptk7 mutant zebrafish models of congenital and idiopathic scoliosis implicate dysregulated Wnt signaling in disease. Nat. Commun. 3:4777. doi: $10.1038 /$ ncomms5777

Heming, T. A., and Buddington, R. K. (1988). "Yolk absorption in embryonic and larval fishes," in Fish Physiology, Vol. XI, eds W. S. Hoar, D. J. Randall, and J. R. Brett (New York, NY: Academic Press), 407-446. doi: 10.1016/s1546-5098(08) 60203-4

Hiroi, J., Kaneko, T., Seikai, T., and Tanaka, M. (1998). Developmental sequence of chloride cells in the body skin and gills of Japanese flounder (Paralichthys olivaceus) larvae. Zool. Sci. 15, 455-460. doi: 10.2108/0289-0003(1998)15[455: DSOCCI]2.0.CO;2

Islam, M. S., Milstein, A., and Wahab, M. A. (2005). Production and economic return of shrimp aquaculture in coastal ponds of different sizes and with different management regimes. Aquacult. Int. 13, 489-500.

Jahan, A., Nipa, T. T., Islam, S. M. M., Uddin, M. H., Islam, M. S., and Shahjahan, M. (2019). Striped catfish (Pangasianodon hypophthalmus) could be suitable for coastal aquaculture. J. Appl. Ichthyol. 35, 994-1003.

Jomori, R. K., Luz, R. K., and Portella, M. C. (2012). Effect of salinity on larval rearing of Pacu, Piaractus mesopotamicus, a freshwater species. J. World Aquacult. Soc. 43, 423-432.

Juo, J. J., Kang, C. K., Yang, W. K., Yang, S. Y., and Lee, T. H. (2016). A stenohaline medaka, Oryzias woworae, increases expression of gill $\mathrm{Na}(+), \mathrm{K}(+)$-ATPase and $\mathrm{Na}(+), \mathrm{K}(+), 2 \mathrm{Cl}(-)$ cotransporter 1 to tolerate osmotic stress. Zool. Sci. 33, 414-425. doi: $10.2108 /$ zs 150157

Kaneko, T., Hasegawa, S., Takagi, Y., Tagawa, M., and Hirano, T. (1995). Hypoosmoregulatory ability of eyed-stage embryos of chum salmon. Mar. Biol. 122, 165-170. doi: $10.1007 / b f 00349290$

Kaneko, T., Shiraishi, K., Katoh, F., Hasegawa, S., and Hiroi, J. (2002). Chloride cells during early life stages of fish and their functional differentiation. Fish. Sci. $68,1-9$.

Katoh, F., Shimizu, A., Uchida, K., and Kaneko, T. (2000). Shift of chloride cell distribution during early life stages in seawater-adapted killifish (Fundulus heteroclitus). Zool. Sci. 17, 11-18. doi: 10.2108/zsj.17.11

Kaushik, S. J., Dabrowski, K., and Luque, P. (1982). Patterns of nitrogen excretion and oxygen consumption during ontogenesis of common carp (Cyprinus carpio). Can. J. Fish. Aquat. Sci. 39, 1095-1105.

Kennard, A. S., and Theriot, J. A. (2020). Osmolarity-independent electrical cues guide rapid response to injury in zebrafish epidermis. eLife 9:e62386. doi: 10.7554/eLife.62386

Kopec, W., Loubet, B., Poulsen, H., and Khandelia, H. (2014). Molecular mechanism of $\mathrm{Na}(+), \mathrm{K}(+)$-ATPase malfunction in mutations characteristic of adrenal hypertension. Biochemistry 53, 746-754. doi: 10.1021/bi401425g

Kumar, A., Harikrishna, V., Reddy, A. K., Chada, N. K., and Rani, B. (2017). Salinity Tolerance of Pangasianodon hypophthalmus in Inland saline water: effect on growth, survival and haematological parameters. Ecol. Environ. Conserv. 23, $475-482$.

Lee, S. Y., Lee, H. J., and Kim, Y. K. (2020). Comparative transcriptome profiling of selected osmotic regulatory proteins in the gill during seawater acclimation of chum salmon (Oncorhynchus keta) fry. Sci. Rep. 10:1987. doi: 10.1038/s41598020-58915-6

Li, J., Eygensteyn, J., Lock, R. A. C., Verbost, P. M., Van der Heijden, A. J. H., Wendelaar, B. S. E., et al. (1995). Branchial chloride cells in larvae and juveniles of freshwater tilapia Oreochromis mossambicus. J. Exper. Biol. 198, 2177-2184. doi: $10.1242 /$ jeb.198.10.2177

Mandal, S. C., Kadir, S., and Hossain, A. (2017). Effects of salinity on the growth, survival and proximate composition of Pangas, Pangasius hypothalamus. Bangladesh J. Zool. 48, 141-149. doi: 10.3329/bjz.v48i1.47883

Marimuthu, K., Muthu, N., Xavier, R., Arockiaraj, J., Rahman, M. A., and Sreeramanan Subramaniam, S. (2013). Toxicity of Buprofezin on the Survival of Embryo and Larvae of African Catfish, Clarias gariepinus (Bloch). PLoS One 8, e75545. doi: 10.1371/journal.pone.0075545 
Matern, S. A. (2001). Using temperature and salinity tolerances to predict the success of the shimofurigobi, a recent invader into California. Trans. Am. Fish Soc. 130, 592-599.

McCormick, S. D., Sundell, K., Björnsson, B. T., Brown, C. L., and Hiroi, J. (2003). Influence of salinity on the localization of $\mathrm{Na}+/ \mathrm{K}+$-ATPase, $\mathrm{Na}+/ \mathrm{K}+/ 2 \mathrm{Cl}$ cotransporter (NKCC) and CFTR anion channel in chloride cells of the Hawaiian goby (Stenogobius hawaiiensis). J. Exp. Biol. 206, 4575-4583. doi: 10.1242/jeb.00711

Nielsen, D. L., Brock, M. A., Rees, G. N., and Baldwin, D. S. (2003). Effects of increasing salinity on freshwater ecosystems in Australia. Aust. J. Bot. 51, 655-665.

Paavola, M., Olenin, S., and Leppäkoski, E. (2005). Are invasive species most successful in habitats of low native species richness across European brackish water seas? Estuar. Coast Shelf Sci. 64, 738-750.

Pivovarov, A. S., Calahorro, F., and Walker, R. J. (2018). Na+/K+-pump and neurotransmitter membrane receptors. Invert. Neurosci. 19:1.

Puvaneswari, S., Marimuthu, K., Karuppasamy, R., and Haniffa, M. A. (2009). Early embryonic and larval development of Indian catfish, Heteropneustes fossilis. Eurasian J. Biosci. 3, 84-96. doi: 10.5053/ejobios.2009.3.0.12

Rabbani, G., Rahman, A., Mainuddhin, K., and Shoef, I. J. (2013). Loss and Damage From Salinity Intrusion in Satkhira District, Coastal Bangladesh. Dhaka: Bangladesh Centre for Advanced Studies (BCAS).

Rahman, M. S., Islam, S. M. M., Haque, A., and Shahjahan, M. (2020). Toxicity of the organophosphate insecticide sumithion to embryo and larvae of zebrafish. Toxicol. Rep. 7, 317-323. doi: 10.1016/j.toxrep.2020.02.004

Saravanan, M., Ramesh, M., Petkam, R., and Krishnan, R. (2018). Influence of environmental salinity and cortisol pretreatment on gill $\mathrm{Na}^{+} / \mathrm{K}^{+}-$ATPase activity and survival and growth rates in Cyprinus carpio. Aquacult. Rep. 11, 1-7. doi: 10.1016/j.aqrep.2018.04.002

Sarma, K., Prabakaran, K., Krishnan, P., Grinson, G., and Kumar, A. A. (2013). Response of a freshwater air-breathing fish, Clarias batrachus to salinity stress: an experimental case for their farming in brackish water areas in Andaman, India. Aquacult. Int. 21, 183-196.

Shahjahan, M., Kabir, M. F., Sumon, K. A., Bhowmik, L. R., and Rashid, H. (2017). Toxicity of organophosphorous pesticide sumithion on larval stages of stinging catfish Heteropneustes fossilis. J. Oceanol. Limnol. 35, 109-114.

Strickland, J. D. H., and Parsons, T. R. (1972). A practical handbook of seawater analysis. Bull. Fish. Res. Bd. Can. 167, 21-26.

Styga, J. M., Pienaar, J., Scott, P. A., and Earley, R. L. (2019). Does body shape in Fundulus adapt to variation in habitat salinity? Front. Physiol. 10:1400. doi: 10.3389/fphys.2019.01400

Suresh, A. V., and Lin, C. K. (1992). Tilapia culture in saline water: a review. Aquaculture 106, 201-226. doi: 10.1016/0044-8486(92)90253-h

Swanson, C. (1996). Early development of milkfish: effects of salinity on embryonic and larval metabolism, yolk absorption and growth. J. Fish Biol. 48, 405-421. doi: 10.1111/j.1095-8649.1996.tb01436.x

Varsamos, S., Diaz, J. P., Charmantier, G., Blasco, C., Connes, R., and Flik, G. (2002). Location and morphology of chloride cells during the post-embryonic development of the European sea bass, Dicentrarchus labrax. Anat. Embryol. 205, 203-213. doi: 10.1007/s00429-002-0231-3

Varsamos, S., Nebel, C., and Charmantier, G. (2005). Ontogeny of osmoregulation in postembryonic fish: a review. Comp. Biochem. Physiol. Part A Mol. Integr. Physiol. 141, 401-429. doi: 10.1016/j.cbpb.2005.01.013

Villegas, C. T. (1990). Evaluation of the salinity tolerance of Oreochromis mossambicus, O. niloticus and their F1 hybrids. Aquaculture 85, 281-292. doi: 10.1016/0044-8486(90)90027-k

Walsh, W. A., and Lund, W. A. (1989). Oxygen consumption by eggs of the grubby, Myoxocephalus aenaeus, and the longhorn sculpin, Myoxocephalus octodecemspinosus. Can. J. Zool. 67, 1613-1619.

Watanabe, W. O., Kuo, C. M., and Huang, M. C. (1985). The ontogeny of salinity tolerance in the tilapias Oreochromis aureus, O. niloticus and O. mossambicus $\times$ O. niloticus hybrid, spawned and reared in freshwater. Aquaculture 47, 353-367.

Woo, N. Y. S., and Kelly, S. P. (1995). Effects of salinity and nutritional status on growth and metabolism of Sparus sarba in a closed seawater system. Aquaculture 135, 229-238. doi: 10.1016/0044-8486(95)01003-3

Yanagie, R., Lee, K. M., Watanabe, S., and Kaneki, T. (2009). Ontogenic changes in tissue osmolality and development sequence of mitochondria-rich cells in Mozambique tilapia developing in freshwater. Comp. Biochem. Physiol. A Mol. Integr. Physiol. 154, 263-269. doi: 10.1016/j.cbpa.2009.06.025

Yang, Z., and Chen, Y. F. (2006). Salinity tolerance of embryos of obscure puffer Takifugu obscurus. Aquaculture 253, 393-397. doi: 10.1016/j.aquaculture.2005. 08.014

Young, P. S., and Dueñas, C. E. (1993). Salinity tolerance of fertilized eggs and yolksac larvae of the rabbit fish Siganus guttatus (Bloch). Aquaculture 112, 363-377. doi: 10.1016/0044-8486(93)90396-g

Zoupa, M., and Machera, K. (2017). Zebrafish as an alternative vertebrate model for investigating developmental toxicity-The Triadimefon Example. Int. J. Mol. Sci. 18:817. doi: 10.3390/ijms 18040817

Conflict of Interest: The authors declare that the research was conducted in the absence of any commercial or financial relationships that could be construed as a potential conflict of interest.

Publisher's Note: All claims expressed in this article are solely those of the authors and do not necessarily represent those of their affiliated organizations, or those of the publisher, the editors and the reviewers. Any product that may be evaluated in this article, or claim that may be made by its manufacturer, is not guaranteed or endorsed by the publisher.

Copyright (C) 2021 Hossain, Islam, Ashaf-Ud-Doulah, Ali, Islam, Brown and Shahjahan. This is an open-access article distributed under the terms of the Creative Commons Attribution License (CC BY). The use, distribution or reproduction in other forums is permitted, provided the original author(s) and the copyright owner(s) are credited and that the original publication in this journal is cited, in accordance with accepted academic practice. No use, distribution or reproduction is permitted which does not comply with these terms. 